Finisterra, XXXVII, 74, 2002, pp. 163-166

\title{
TEMAS DE COMÉRCIO E CONSUMO
}

\author{
Teresa Barata Salgueiro ${ }^{1}$
}

Nesta nota fazemos uma chamada de atenção para a publicação pelo GEPE (Gabinete de Estudos e Prospectiva Económica do Ministério da Economia) de um conjunto de obras sobre Comércio, embora a nossa análise incida mais particularmente sobre a obra de Herculano Cachinho.

$\mathrm{Na}$ colecção «Temas de Comércio» saíram em 2002 cinco títulos ${ }^{2}$ da responsabilidade editorial do Observatório do Comércio que divulgam trabalho desenvolvido por este Observatório, seja por execução directa, seja fruto de estudos contratados a equipas de universitários. No total foram efectuados 14 estudos entre 1999 e 2001. Cada um com a sua especificidade, representam um contributo muito valioso para o conhecimento do comércio em Portugal nas suas diversas facetas. Foram muito bem sintetizados e complementados com uma súmula estatística do sector no Relatório "Observar o Comércio em Portugal» cuja difusão praticamente coincidiu com a extinção do Observatório.

Publicado no mesmo ano, mas com preparação anterior, o livro de Herculano Cachinho, "O Comércio Retalhista Português: Pós-Modernidade, Consumidores e Espaço» insere-se na colecção "Temas de Economia» e tem características algo diferentes. Produto da tese de doutoramento do autor, embora com redução substancial em relação ao trabalho original, a elaboração teórica tem maior desenvolvimento nesta obra do que nas outras. Em paralelo com a apresentação das mudanças ocorridas no sistema retalhista em Portugal, tem o grande mérito de trazer o consumo para a dianteira dos mecanismos da sua compreensão ao explorar o papel dos actores, designadamente o dos consumidores na pós-modernidade.

Os trabalhos sobre a geografia do comércio em Portugal têm os primórdios nos anos 70, com Simões Lopes e Jorge Gaspar, no contexto das correntes positivistas associadas à aplicação da Teoria dos Lugares Centrais ao povoamento e

1 Professora de Geografia na Faculdade de Letras da Universidade de Lisboa, investigadora do Centro de Estudos Geográficos. E-mail: tbs@mail.doc.fl.ul.pt

2 AA.VV., Novos comércios, novos consumos; C. ForTuna (coord.), Cultura, corpo e comércio; T. Barata Salgueiro e outros, 2002, Estratégias empresariais, emprego e empregabilidade no comércio; Margarida Pereira e J. A. Teixeira (coord.), Horários do comércio: liberalizar ou condicionar?; C. BALSAS, Urbanismo comercial e parcerias públicas-privadas. 
à estrutura urbana do comércio e das práticas de abastecimento em função da distância. A grande mudança ocorrida nas formas de venda, nas práticas de compras e nas paisagens comerciais, nos anos 80 , explica o crescimento do interesse por esta actividade e o alargar do quadro explicativo, numa primeira fase a abordagens de tipo estruturalista baseadas na teoria económica das mudanças na oferta e na procura. Embora Barata Salgueiro (1989) situe o enfoque nos actores da mudança e até mesmo nos consumidores, o seu contributo é essencialmente estruturalista. Apesar de evidenciar algum interesse pela questão do consumo nas vivências individuais e de valorizar, nos centros comerciais, outras funções para além das compras, como as de encontro, passeio e ocupação dos tempos livres, o que a leva a intitular o quadro explicativo de «modelo convivial numa sociedade consumista», essa linha de explicação está pouco desenvolvida num quadro ainda marcado pelo positivismo.

A ruptura trazida por Herculano Cachinho deriva do facto de deslocar a explicação do sistema comercial e das análises funcionalistas de cariz estruturalista para o consumo, para a emergência dos valores do consumo na pósmodernidade e pela importância que atribui ao valor simbólico dos produtos e dos sistemas comerciais, justaposto ao valor factual da materialidade do território. Aproxima-se assim das novas correntes da Geografia Cultural que atribuem grande relevância aos sentidos, neste caso ao consumo de sentidos em vias de assumir um papel mais eloquente que o dos objectos.

$\mathrm{O}$ consumo surge como um processo eminentemente cultural que combina processos materiais e representações simbólicas, sendo uma actividade criadora de sentidos. Ao mesmo tempo, verifica-se a desmaterialização crescente do consumo, quer de objectos, quer de lugares, uma vez que os espaços de consumo são cada vez mais próximos dos espaços da representação de Lefebvre, lugares da hiper-realidade.

Nos argumentos do autor devemos salientar o papel central atribuído aos diversos actores e às suas relações, bem como à dimensão espacial dos sistemas comerciais e das práticas de consumo, argumento bem expresso na alegoria que estabelece com o tear.

Depois de uma longa «Introdução» com os objectivos do estudo e o essencial da sua argumentação, na $1 .^{\mathrm{a}}$ parte encontramos uma apresentação muito completa da mudança na organização do comércio retalhista, enquanto na $2 .^{a}$ parte estuda os chamados "motores da mudança», os actores (operadores de venda, produtores, consumidores e o Estado) nas suas relações múltiplas, bem como o ambiente em que operam as empresas. Este remete para o contexto das relações, para o papel do espaço enquanto vector activo das formações sociais, ou mais correctamente, por isso mesmo, das formações sócio espaciais, para retomar um conceito importante em Milton Santos.

Para além da questão do consumo, amplamente problematizada no capítulo 5, outro importante contributo a nível teórico encontra-se na valorização do papel do espaço que faz desta obra um trabalho indiscutivelmente marcante na Geografia, tanto mais quanto o debate epistemológico sobre o espaço tem sido 
escasso na Geografia portuguesa. H. Cachinho faz um bom ponto de situação do debate sobre o espaço encarado dum triplo ponto de vista, enquanto ambiente material, enquanto diferença, enquanto espacialidade social. Os dois primeiros sentidos têm estado mais presentes na Geografia do que o último que melhor serve a abordagem pela óptica dos actores e do consumo. É no quadro do entendimento do espaço enquanto espacialidade social que o autor situa o enfoque nas práticas de consumo e nas diferenças que elas apresentam entre a modernidade e a pós-modernidade, embora na produção do espaço comercial de Leiria os três entendimentos do conceito de espaço sejam aplicados. Assim, «o espaço contextualiza as acções dos agentes e medeia as suas relações... a sua textura incorpora sempre elementos e processos globais e locais... Poderoso agente de diferenciação [o espaço] participa também na construção da identidade dos sistemas de venda a retalho» (p. 225).

O capítulo 6 é dedicado à compreensão dos consumidores nos espaços da pós-modernidade, época na qual o consumo é um componente estruturador das identidades. Discute como o "consumidor estatístico» dos estudos de mercado foi substituído pelo "consumidor-indivíduo» para o qual analisa as dimensões mais pertinentes para compreender as mudanças no sistema retalhista.

Depois da discussão geral à escala do país, H. Cachinho analisa Leiria como caso de estudo «não só para comprovar a relação entre as alterações do ambiente comercial e as mudanças no comércio retalhista, mas também para perceber que os mecanismos causais se alteram com a mudança de escala» (p. 18). Assim, a 3. ${ }^{\mathrm{a}}$ parte é dedicada à produção do espaço comercial na cidade de Leiria compreendendo 2 capítulos, o 7 sobre a dinâmica do aparelho comercial na cidade e o 8 sobre os actores (nas suas relações e com a trama) e as várias leituras do espaço (ambiente material, diferença, espacialidade social) que serve de palco e contexto às práticas e representações dos actores, comprovando a sua tese, simbolizada pelo tear, no caso estudado. "As transformações do tecido comercial.... reflectem não só a entrada no sistema de novos actores como uma mudança profunda no comportamento dos já existentes» (p. 414). Confirma que «a recentragem da oferta e do consumo no valor simbólico das mercadorias e dos estabelecimentos, na valorização da sua imaterialidade, encontra-se entre as mudanças mais significativas que o sistema comercial da cidade experimentou nos últimos anos» (p. 415) e contribui para perceber melhor o sucesso de alguns comerciantes e as dificuldades de outros.

Privilegiando a análise da cidade e da estrutura comercial na óptica do consumo, o autor conclui que Leiria é «uma cidade segmentada, senão mesmo fragmentada que os indivíduos vivem na sua totalidade» (p.416), unificando práticas de abastecimento que combinam deslocações de alcance e ritmos muitos diferentes com destinos diversos. Alguns dos lugares frequentados são verdadeiros arranjos cenográficos, paisagens simuladas de uma hiper-realidade, pois que «ancoradas no simbolismo da arquitectura e do design, no valor--signo das mercadorias e nas experiências do consumo, os novos espaços 
comerciais fazem da cidade um espectáculo e os indivíduos-consumidores os seus espectadores e actores» (p. 428).

De um modo geral os livros de GEPE são cuidados e bonitos e, por isso mesmo, atraentes pelo grafismo e qualidade de impressão. Mas, por vezes, o grafismo prejudica o autor, como se vê nos mapas da cidade de Leiria que perderam clareza devido à cor do fundo, ou o leitor, como sucede com a apresentação absurda dos índices nos volumes de responsabilidade do Observatório do Comércio que não respeitam as regras de leitura consagradas. 